\title{
Eecherenal
}

\section{Lower chronic hepatitis B in South Asia despite all odds: Bucking the trend of other infectious diseases}

\author{
Pankaj Puri, Sharad Srivastava
}

Department of Gastroenterology Command Hospital (SC),

Pune -411040 , India

Correspondence:

Dr. Pankaj Puri

Email:puripankaj@gmail.com
Hepatitis B virus (HBV) infection remains a significant global health problem. As per estimates of the World Health Organization (WHO), approximately 2 billion people have been infected worldwide, which represents one-third of the world population. Of these, more than 350 million (5-7\% of the world's population) suffer from chronic HBV infection. ${ }^{1,2}$ Approximately $15-40 \%$ of the infected patients will develop life-threatening liver diseases (cirrhosis, liver failure and hepatocellular carcinoma) resulting in 600,000 to 1.2 million deaths per year due to $\mathrm{HBV} .{ }^{3,4}$ Epidemiological data on $\mathrm{HBV}$ infection is therefore important for strategies to tackle the spread of the disease.

Based on the prevalence of hepatitis B surface antigen (HBsAg), countries are classified as having high $(\geq 8 \%)$, intermediate $(2-7 \%)$ or low $(<2 \%) \mathrm{HBV}$ endemicity. Areas of high endemicity (where $\geq 8 \%$ of the population is HBsAg positive) include South-East Asia, China, most of Africa, most of Pacific Islands, the Amazon basin and parts of the Middle East. The areas of intermediate endemicity (2-7\%) include South Asia, Eastern and Southern Europe, Russia and Central and South America. On the other hand areas with low endemicity $(<2 \%)$ include United States, Western Europe and Australia. ${ }^{5}$

The South Asian countries, a contiguous block of countries which have been classified together as Global Burden of Disease Regions include Afghanistan, Bangladesh, Bhutan, India, Nepal and Pakistan. ${ }^{6}$ People in South Asia are at a higher risk of developing infectious diseases due to poverty and its associated problems of unhygienic living conditions, malnutrition, illiteracy, and poor access to clean water, toilet facilities, and quality health care. Spread of HBV infection in many South Asian countries is attributed to unsafe blood supply, reuse of contaminated syringes, lack of maternal screening to prevent perinatal transmission and delay in the introduction of hepatitis B vaccine. ${ }^{7}$ However, it is intriguing that bucking the trend of other infectious diseases, the prevalence of HBV in South Asian countries is lower than some of the more affluent neighbors in the South East Asian countries. Re-emphasizing the lower prevalence of HBV in South Asia is an article by Shrestha et $\mathrm{al}^{8}$ in this issue of Tropical Gastroenterology, which shows that the prevalence of HBV in Nepal is even lower than that in other countries of South Asia.

\section{HBV in India}

India is the largest nation in the region and by its sheer population bears the bulk of HBV burden in South Asia and accounts for 10-15\% of the entire pool of HBV carriers of the world. ${ }^{9}$ It has been estimated that India has over 40 million HBV carriers. Of the 25 million infants born every year in India, it is estimated that over one million run the lifetime risk of developing chronic HBV infection. Every year over 100,000 Indians die due to illnesses related to HBV infection. ${ }^{10}$ 
The overall rate of HBsAg positivity has been reported to range between $2-4.7 \% .{ }^{11,12} \mathrm{~A}$ meta-analysis found the point prevalence of $\mathrm{HBV}$ to be $2.4 \%$ in non-tribal populations and $15.9 \%$ among tribal populations. ${ }^{13}$ However, a disproportionately high amount of data is from a select few areas. In a repeat calculation of the prevalence of $\mathrm{HBV}$ in India using population-weights, it was estimated that the pointprevalence of hepatitis B among non-tribal and tribal populations was 3.07\% (95\% CI: $2.5-3.64)$ and $11.85 \%$ (95\% CI: 10.76-12.93), respectively and the overall prevalence was $3.70 \%$ (95\% CI: 3.17-4.24), (corresponding to a chronic carrier rate of $2.96 \%)^{14}$

A higher prevalence of $\mathrm{HBV}$ infection has been reported in patients with human immunodeficiency virus (HIV) positive intravenous drug users in Manipur in northeast India ${ }^{15}$ and in tribals. The point prevalence of HBsAg in the Idu Mishmi tribe of Arunachal Pradesh, which has common ancestral roots with the Lobha tribe of Tibet, was found to be $21.2 \% .{ }^{16}$ Very high levels of HBsAg positivity have also been reported in the tribes of Andaman and Nicobar Islands (Nicobarese tribe - 23.3\%, Shompen tribe - 37.8\%, Jarawa tribe - 65\%). ${ }^{17,18}$ The high endemicity of $\mathrm{HBV}$ infection in the tribal populations has been attributed to inbreeding, poor hygienic living conditions, close person-to-person contact and certain socio-culture practices which may facilitate transmission of HBV. ${ }^{19}$

While earlier studies have shown a prevalence of $\mathrm{HBsAg}$ positivity of 2.3-6.3\% in pregnant women, ${ }^{20-23}$ Dwivedi et $\mathrm{al}^{24}$ have shown a lower prevalence rate of $0.9 \%$. However, unlike most studies showing lower levels of $\mathrm{HBeAg}$ positivity in $\mathrm{HBV}$ infected pregnant women, ${ }^{12}$ Dwivedi et $\mathrm{al}^{24}$ reported a high replicative rate, with $56.8 \%$ of the patients being $\mathrm{HBeAg}$ positive.

The common genotypes reported from most parts of India are genotype $\mathrm{A}$ followed by D. ${ }^{25-31}$ However, gentotype $\mathrm{C}$ has also been reported besides genotypes $\mathrm{A}$ and $\mathrm{D}$ from eastern India and the northeastern Indian state of Arunachal Pradesh. ${ }^{12,32,33}$ There are isolated reports of genotype E, F and $\mathrm{G}$ from India. $32,34,35$

\section{HBV in Nepal}

Shrestha et $\mathrm{al}^{8}$ in this issue of Tropical Gastroenterology report that the prevalence of HBV in Nepal is $0.9 \%$. The low prevalence of HBV in Nepal has also been earlier noted in 1987 by Nakashima et al. ${ }^{36}$ However, like India, Nepal has its own share of higher prevalence communities. The high prevalence of HBV in the migrant Tibetan population has been attributed to their Tibetan ancestory. ${ }^{8}$ Chiba et $\mathrm{al}^{37}$ have however shown low prevalence of HBV in Sherpas despite their Tibetan ancestry. Besides, nucleotide sequencing of the PreS1, PreS2 and S genes among Sherpas was similar to that prevalent in Nepalese but rare in native Tibetans, suggesting transmission within Nepal rather than association with ancestral migration from Tibet, as the origin.

The HBsAg prevalence among pregnant women in Nepal is low $(0.5 \%)$ and limited data has shown no evidence of replication. ${ }^{8}$ The commonest HBV genotypes in Nepal are D (69\%) followed by genotype A (22\%); while mixed infections (4.4\%) and genotype C (4.4\%) occur rarely. ${ }^{8}$

\section{HBV in Bangladesh}

The prevalence of $\mathrm{HBV}$ in Bangladesh has been reported to vary from 3 to $7.5 \% .{ }^{38-44} \mathrm{HBV}$ prevalence in the healthy adult population in Bangladesh appears to be on the decline since earlier reports of $7.2-7.5 \%{ }^{43,44}$ to $5.5 \%$ in recent data. ${ }^{39}$ The prevalence of HBsAg positivity in pregnant women has been reported to be $0.4 \%$ in the rural population ${ }^{45}$ and $3.5 \%$ in urban regions. ${ }^{46}$ The subgenotype $\mathrm{C} 2$, which has been isolated in China and South-East Asia has also been detected in Bangladesh. ${ }^{47}$

\section{HBV in Bhutan}

There is limited data available from the other mountain kingdom, Bhutan, located to the northeast of India. HBsAg was found in $5.9 \%$ of the samples from the general population $5.2 \%$ in children, $5.6 \%$ in young people and $6.3 \%$ in adults) and in $5.4 \%$ of pregnant women. Of the HBsAg-positive pregnant women, $29.1 \%$ were $\mathrm{HBeAg}$ negative and $\mathrm{HBV}$ DNA positive. ${ }^{48}$ Surprisingly the HBsAg carrier rate was found to be low $(0.9 \%)$ in Bhutanese refugees residing in Nepal. ${ }^{49}$

\section{HBV in Pakistan}

Reviews of published literature have estimated that there are 7-9 million carriers of HBV with a carrier rate of 2.6-5\% in Pakistan. ${ }^{50,51}$ A prevalence survey on hepatitis B infections to obtain national estimates showed a HBsAg positivity of $2.5 \% .^{52}$ A prevalence of 5-7\% $\mathrm{HBsAg}$ positivity has been reported from Sindh. ${ }^{53,54}$ A high HBsAg positivity of $9.8 \%$ has been detected in Balochistan. ${ }^{55}$ Armed conflicts and political 
instability in Afghanistan have lead to a huge influx of refugees into the neighboring provinces of Pakistan. Hepatitis B is highly endemic among these Afghan refugees. ${ }^{56,57}$

Studies on pregnant women in Pakistan showed HBV infection rates of $2.9 \%$ (range $1.8-12.6 \%$ ). ${ }^{58} \mathrm{HBeAg}$ positivity has been shown to be $22.9 \%$ in HBsAg-positive mothers. ${ }^{59}$

Genotype D has been reported as the most prevalent genotype in Pakistan. ${ }^{60} \mathrm{~A}$ summary of reports from Pakistan show the average prevalence of HBV genotypes as, D (62\%), A (14\%), C (6\%), other genotypes, including B (4\%), and recombinants (10\%). The genotypes $\mathrm{E}$ and $\mathrm{F}$ are unusual in the Pakistani population. ${ }^{61}$ However, Awan et $\mathrm{al}^{62}$ in patients from four different geographical provinces of Pakistan, found contradictory results, with Genotype $\mathrm{C}$ as the most prevalent genotype.

\section{HBV in Afghanistan}

The country has been ravaged by prolonged armed conflicts resulting in poverty, increasing illiteracy, breakdown of social structure and increase in high-risk behavior of intravenous drug abuse. There has been paucity of community based epidemiologic data about the actual prevalence rate of HBV from Afghanistan. The limited data available from Afghanistan shows a HBV prevalence of $1.9 \% .{ }^{63}$ Prevalence of HBV in IV drug users has been reported as 5.8-6.5\%..$^{64-65}$

Evaluation of genotypes from Afghanistan showed that genotype $\mathrm{D}(35.67 \%)$ was the predominant genotype followed by genotype $\mathrm{C}(32.16 \%)$, genotype $\mathrm{A}(19.30 \%)$, and genotype B $(7.02 \%){ }^{66}$

\section{Interpreting the epidemiology of $\mathrm{HBV}$ in south Asia}

The epidemiology of HBV in South Asia is depicted in Table 1.
The data on prevalence of HBV from South Asia is sketchy with scarcity of large nation-wide epidemiological studies. As more data becomes available it may not be surprising to find a higher prevalence in some countries like Afghanistan where the available data shows only $1.9 \%$ prevalence of HBV. In comparison to these prevalence rates of HBV in South Asia, the South-East Asian countries in general have a higher prevalence with the highest rates in Taiwan $(>10 \%)$ and Thailand $(>8 \%){ }^{67}$

Looking at the prevalence of HBV in South Asia, two questions arise in one's mind. First, how is it that the prevalence of HBV is lower in South Asia as compared to South-East Asia despite the lower socio-economic status, illiteracy, low immunization rates, regional conflict and high-risk tribal populations? Second, how does one explain the lower prevalence of HBV in Nepal as reported in this issue by Shrestha et al? ${ }^{8}$

This lower transmission of HBV in South Asia, despite all odds, is due to the fact that unlike the vertical transmission of HBV in South-East Asia, the predominant mode of transmission is horizontal in South Asia as shown by Gupta et $\mathrm{al}^{68}$ from North India and Shrestha et $\mathrm{al}^{8}$ from Nepal. The precise mode of horizontal transmission is unknown but it may be due to contact of non-intact skin or mucous membranes with tears, saliva or blood containing secretions or through sharing of toothbrushes. The age of acquisition of HBV is an important determinant of outcome; the earlier the age, the higher the likelihood of chronicity. The risk of chronicity in HBV infection acquired at different ages ranges from $>90 \%$ in newborns, $30 \%$ in children aged $2-5$ years and $<5 \%$ in adults. Neonates with vertically acquired $\mathrm{HBV}$ infection have a higher chance of chronicity and serve as a reservoir of the infection. On the other hand, infection acquired in adulthood is more likely to present as acute hepatitis B and contribute less to the burden

Table 1: Epidemiology of Chronic hepatitis B in South Asia

\begin{tabular}{|c|c|c|c|c|}
\hline & $\begin{array}{l}\text { Overall prevalence } \\
\text { of } \mathrm{HBV}\end{array}$ & $\begin{array}{l}\text { High prevalence } \\
\text { regions }\end{array}$ & $\begin{array}{l}\text { Prevalence of } \\
\mathrm{HBV} \text { in pregnancy }\end{array}$ & Genotypes \\
\hline Afghanistan* & $1.9 \%$ & & & $\mathrm{D}>\mathrm{C}>\mathrm{A}>\mathrm{B}$ \\
\hline Bangladesh ${ }^{*}$ & $5.5 \%$ & & Rural: $0.4 \%$, Urban: $3.5 \%$ & \\
\hline Bhutan & $5.9 \%$ & & $5.4 \%(\mathrm{HBsAg}+\mathrm{ve}: 29.1 \%)$ & $-\mathrm{C} 2$ \\
\hline India & $2.96 \%$ & $\begin{array}{l}\text { - Tribals (Arunachal Pradesh, } \\
\text { Andaman \& Nicobar) } \\
\text { - IVDU\# Manipur }\end{array}$ & $\begin{array}{l}0.9-6.3 \% \\
(\text { HBeAg +ve: } 12-57 \%)\end{array}$ & $\begin{array}{l}\text { - D >A } \\
\text { - Eastern India: C } \\
\text { - Isolated reports: E, F, G }\end{array}$ \\
\hline Nepal & $0.9 \%$ & - Tibetan community & $0.5 \%(\mathrm{HBeAg}+\mathrm{ve}: 0 \%)$ & - D >A-Rare: C \\
\hline Pakistan & $2.5 \%$ & $\begin{array}{l}\text { - Balochistan } \\
\text { - Afghan Refugees }\end{array}$ & $\begin{array}{l}2.9 \% \text { (range } 1.8-12.6 \%) \\
(\mathrm{HBeAg}+\mathrm{ve}: 22.9 \%)\end{array}$ & $\begin{array}{l}\text { - } \mathrm{D}>\mathrm{A}>\mathrm{C} \\
\text { (?Commonest genotype C) } \\
\text { - Rare: E, F }\end{array}$ \\
\hline
\end{tabular}

${ }^{*}$ Limited data

\# IVDU- Intravenous drug users 
of chronic HBV.

The differences in HBV transmission in South-East Asia and South Asia may be related to differences in genotype distribution and mutations in the HBV genome. Genotypes B and $\mathrm{C}$ are most prevalent in highly endemic areas where vertical transmission is the primary mode of transmission. In contrast, HBV genotypes A, D, E, F and G are detected in areas where horizontal or sexual transmission is more common. Pockets of high prevalence of genotype $\mathrm{C}$ in Arunachal Pradesh have a high prevalence of HBV. Infection with HBV genotype A is associated with increased replication and high concentration of HBV DNA in body fluids of HBV carriers, which lead to an increased risk of horizontal transmission. ${ }^{69,70}$ Different genotypes may be preferentially transmitted by different modes. ${ }^{71} \mathrm{HBV}$ genomic heterogeneity may also play an important role in $\mathrm{HBV}$ intrauterine infection and certain mutations in preS1 region, preS2 region and $\mathrm{S}$ region might infect fetuses more readily. ${ }^{72}$

The second question that one needs to address is how we interpret the lower prevalence of HBV in Nepal as compared to the rest of South Asia. In Nepal the transmission may be occurring at an older age as postulated by Shrestha et al. ${ }^{8}$ The mountain kingdom of Nepal has remained relatively insulated to the spread of HBV as compared to its neighbors. The other South Asian countries, have their own peculiar issues like armed conflicts and terrorism resulting in injuries, transfusions and refugees, high-risk tribal populations, blood donation by paid donors, etc. Besides, reports of genotype $\mathrm{C}$ in pockets of the other South Asian countries may have a role in transmission of the virus. Based on the distribution of hepatitis B markers in different age groups in Nepal, Shrestha et $\mathrm{al}^{8}$ have postulated that the mode of transmission in Nepal is horizontal transmission acquired in the adolescent period. However, they have not offered any explanation for the same based on any socio-cultural behavior patterns in Nepal. The prevalence of $\mathrm{HBeAg}$ in $\mathrm{HBsAg}$-positive pregnant Nepalese women was found to be zero. This however is an extreme figure, which would require validation by larger studies.

\section{Conclusion}

The burden of vertical and horizontal transmission has been debated to determine the importance of the birth dose in immunization programs. While it is stated that the transmission of HBV in South Asia is horizontal, the contribution by vertical transmission may be underestimated if we look at the high prevalence of replicative markers in $\mathrm{HBsAg}$-positive pregnant women as reported by Dwivedi et al. ${ }^{24}$

As a result of vaccination, carrier rates of hepatitis B surface antigen in children plummeted from $9.8 \%$ to $0.7 \%$ in Taiwan. ${ }^{73}$ South Asia with its large burden of $\mathrm{HBV}$ is still far from universal immunization. Despite lower prevalence of $\mathrm{HBV}$, due to its large population, South Asia contributes significantly to the global burden of chronic HBV. It is time for South Asia to take note and consolidate the advantage of lower prevalence of $\mathrm{HBV}$ in the area by targeting transmission of the virus to further control the morbidity and mortality related to HBV.

\section{References}

1. World Health Organization. Hepatitis B. World Health Organization Fact Sheet 204 (Revised August 2008), http://who.int/inf-fs/en/fact204.html.

2. Lavanchy D. Hepatitis B virus epidemiology, disease burden, treatment, and current and emerging prevention and control measures. J Viral Hepat. 2004;11:97-107.

3. Lok AS. Chronic hepatitis B. N Engl J Med. 2002;346:1682-3.

4. Goldstein ST, Zhou F, Hadler SC, Bell BP, Mast EE, Margolis HS. A mathematical model to estimate global hepatitis B disease burden and vaccination impact. Int $J$ Epidemiol. 2005;34:1329-39.

5. Te HS, Jensen DM. Epidemiology of hepatitis B and C viruses: a global overview. Clin Liver Dis. 2010;14:1-21.

6. Ott JJ, Stevens GA, Groeger J, Wiersma ST. Global epidemiology of hepatitis B virus infection: new estimates of age-specific HBsAg seroprevalence and endemicity. Vaccine. 2012;30:2212-9.

7. Zaidi AK, Awasthi S, deSilva HJ. Burden of infectious diseases in South Asia. BMJ. 2004;328:811-5.

8. Shrestha SM, Shrestha S. Chronic Hepatitis B in Nepal. Trop Gastroenterol 2012;33:95-101

9. Datta S. An overview of molecular epidemiology of hepatitis B virus (HBV) in India. Virol J. 2008;5:156.

10. World Health Organization. Introducing Hepatitis B Vaccine in Universal Immunization Programme in India - A Brief Scenario, http://www.whoindia.org/en/section6/section8.htm.

11. Thyagarajan SP, Jayaram S, Mohanavalli B. Prevalence of HBV in general population in India. In: Sarin SK, Singal AK, editors. Hepatitis B in India: problems and prevention. New Delhi: CBS; 1996. p. 5-16.

12. Abraham P. Viral Hepatitis in India. Clin Lab Med 2012; http:// dx.doi.org/10.1016/j.cll.2012.03.003.

13. Batham A, Narula D, Toteja T, V Sreenivas, Puliyel JM. Systematic review and meta-analysis of data of prevalence of hepatitis B in India. Indian Pediatr. 2007;44:663-74.

14. Batham A, Gupta MA, Rastogi P, Garg S, Sreenivas V, Puliyel JM. Calculating prevalence of hepatitis B in India: using population weights to look for publication bias in conventional meta-analysis. Indian J Pediatr. 2009;76:1247-57. 
15. Saha MK, Chakrabarti S, Panda S, Naik TN, Manna B, Chatterjee A, et al. Prevalence of HCV \& HBV infection amongst HIV seropositive intravenous drug users \& their non-injecting wives in Manipur, India. Indian J Med Res. 2000;111:37-9.

16. Biswas D, Borkakoty BJ, Mahanta J, Jampa L, Deouri LC. Hyperendemic foci of hepatitis B infection in Arunachal Pradesh, India. J Assoc Physicians India. 2007; 55:701-4.

17. Murhekar MV, Murhekar KM, Sehgal SC. Alarming prevalence of hepatitis-B infection among the Jarawasa-primitive Negrito tribe of Andaman and Nicobar Islands, India. J Viral Hepat. 2003;10:232-3.

18. Murhekar MV, Murhekar KM, Das D, Arankalle VA, Sehgal SC. Prevalence of hepatitis B infection among the primitive tribes of Andaman \& Nicobar Islands. Indian J Med Res. 2000;111:199-203.

19. Murhekar MV, Murhekar KM, Sehgal SC. Epidemiology of hepatitis B virus infection among the tribes of Andaman and Nicobar Islands, India. Trans $R$ Soc Trop Med Hyg. 2008;102:729-34.

20. Pande C, Sarin SK, Patra S, Bhutia K, Mishra SK, Pahuja S, et al. Prevalence, risk Factors and virological profile of chronic hepatitis $\mathrm{B}$ virus infection in pregnant women in India. J Med Virol. 2011;83:962-7.

21. Biswas SC, Gupta I, Ganguly NK, Chawla Y, Dilawari JB. Prevalence of hepatitis B surface antigen in pregnant mothers and its perinatal transmission. Trans $R$ Soc Trop Med Hyg. 1989;83:698-700.

22. Gill HH, Majumdar PD, Dhunjibhoy KR, Desai HG. Prevalence of hepatitis $\mathrm{B}$ e antigen in pregnant women and patients with liver disease. J Assoc Physicians India. 1995;43:247-8.

23. Mittal SK, Rao S, Rastogi A, Aggarwal V, Kumari S. Hepatitis B - potential of perinatal transmission in India. Trop Gastroenterol. 1996;17:190-2.

24. Dwivedi M, Misra SP, Misra V, Pandey A, Pant S, Singh R, et al. Seroprevalence of hepatitis B infection during pregnancy and risk of perinatal transmission. Indian J Gastroenterol. 2011;30:66-71.

25. Madan K, Batra Y, Sreenivas V, Mizokami M, Tanaka Y, Chalamalasetty SB, et al. HBV genotypes in India: do they influence disease severity? Hepatol Res. 2009;39:157-63.

26. Kumar R, Pahal V, Singh J. Prevalence of genotype D and precore/ Core promoter mutations in hepatitis B virus-infected population of North India. J Clin Exp Hepatol. 2011;1:73-6.

27. Thakur V, Guptan RC, Kazim SN, Malhotra V, Sarin SK. Profile, spectrum and significance of HBV genotypes in chronic liver disease patients in the Indian subcontinent. J Gastroenterol Hepatol. 2002;17:165-70.

28. Gandhe SS, Chadha MS, Arankalle VA. Hepatitis B virus genotypes and serotypes in Western India: lack of clinical significance. J Med Virol. 2003;69:324-30.

29. Banerjee A, Datta S, Chandra PK, Roychowdhury S, Panda CK, Chakravarty R. Distribution of hepatitis B virus genotypes: phylogenetic analysis and virological characteristics of genotype C circulating among HBV carriers in Kolkata, Eastern India. World J Gastroenterol. 2006;12:5964-71.

30. Kumar A, Kumar SI, Pandey R, Naik S, Aggarwal R. Hepatitis B virus genotype $\mathrm{A}$ is more often associated with severe liver disease in northern India than is genotype D. Indian J Gastroenterol. 2005;24:19-22.

31. Chattopadhyay S, Das BC, Kar P. Hepatitis B virus genotypes in chronic liver disease patients from New Delhi, India. World J Gastroenterol. 2006;12:6702-6.

32. Kumar K, Kumar M, Rahaman SH, Singh TB, Patel SK, Nath G. Distribution of Hepatitis B virus genotypes among healthy blood donors in eastern part of North India. Asian J Transfus Sci. 2011;5:144-9.

33. Borkakoty BJ, Mahanta J, Biswas D. Circulating genotypes of hepatitis B virus in Arunachal Pradesh. Indian J Med Res. 2008; 127:65-70.

34. Singh J, Dickens C, Pahal V, Kumar R, Chaudhary R, Kramvis A, et al. First report of genotype $\mathrm{E}$ of hepatitis B virus in an Indian population. Intervirology. 2009;52:235-8.

35. Kumar GT, Kazim SN, Kumar M, Hissar S, Chauhan R, Basir $\mathrm{SF}$, et al. Hepatitis B virus genotypes and hepatitis B surface antigen mutations in family contacts of hepatitis B virus infected patients with occult hepatitis B virus infection. J Gastroenterol Hepatol. 2009;24:588-98.

36. Nakashima K, Kashiwagi S, Noguchi A, Hirata M, Hayashi J, Kawasaki T, et al. Human T lymphotropic virus type-I, and hepatitis A,B and C viruses in Nepal: a serological survey. J Trop Med Hyg. 1995;98:347-50.

37. Chiba H, Takezaki T, Neupani D, Kim J, Yoshida S, Mizoguchi E, et al. An epidemiological study of HBV, HCV and HTLV-1 in Sherpas of Nepal. Asian Pac J Cancer Prev. 2004;5:370-3.

38. Zaki H, Darmstadt GL, Baten A, Ahsan CR, Saha SK. Seroepidemiology of hepatitis B and delta virus infections in Bangladesh. J Trop Pediatr. 2003;49:371-4.

39. Mahtab MA, Rahman S, Karim MZ, Khan M, Foster G, Solaiman $\mathrm{S}$, et al. Epidemiology of hepatitis B virus in Bangladeshi general population. Hepatobiliary Pancreat Dis Int. 2008;7:595-600.

40. Rudra S, Chakrabarty P, Poddar B. Prevalence of hepatitis B and hepatitis $\mathrm{C}$ virus infection in human of Mymensingh, Bangladesh. Mymensingh Med J. 2011;20:183-6.

41. Ashraf H, Alam NH, Rothermundt C, Brooks A, Bardhan P, Hossain L, et al. Prevalence and risk factors of hepatitis B and C virus infections in an impoverished urban community in Dhaka, Bangladesh. BMC Infect Dis. 2010;10:208.

42. Gibney L, Saquib N, Metzger J, Choudhury P, Siddiqui M, Hassan M. Human immunodeficiency virus, hepatitis B, C and $\mathrm{D}$ in Bangladesh's trucking industry: prevalence and risk factors. Int J Epidemiol. 2001;30:878-84.

43. Islam MN, Islam KM, Islam N. Hepatitis-B virus infection in Dhaka, Bangladesh. Bangladesh Med Res Council Bull. 1984;10:1-6.

44. Khan M, Ahmad N. Seroepidemiology of HBV and HCV in Bangladesh. Int Hepatol Comm. 1996;5:27-9.

45. Shamsuzzaman M, Singhasivanon P, Kaewkungwal J, Lawpoolsri S, Tangkijvanich P, Gibbons RV, et al. Hepatitis B among pregnant women attending health care facilities in rural Bangladesh. Southeast Asian J Trop Med Public Health. 2011;42:1410-3.

46. Rumi MA, Begum K, Hassan MS, Hasan SM, Azam MG, Hasan $\mathrm{KN}$, et al. Detection of hepatitis B surface antigen in pregnant women attending a public hospital for delivery: implication for vaccination strategy in Bangladesh. Am J Trop Med Hyg. 
1998;59:318-22.

47. Norder H, Couroucé AM, Coursaget P, Echevarria JM, Lee SD, Mushahwar IK, et al. Genetic diversity of hepatitis B virus strains derived worldwide: genotypes, subgenotypes, and HBsAg subtypes. Intervirology. 2004;47:289-309.

48. Da Villa G, Andjaparidze A, Cauletti M, Franco E, Roggendorf M, Sepe A, et al. Viral hepatitis in the Bhutanese population: preliminary results of a seroepidemiological investigation. Res Virol. 1997;148:115-7.

49. Shah BK, Bhattacharya S, Parija SC. Seroprevalence of hepatitis B virus among Bhutanese refugees residing in Nepal. Kathmandu Univ Med J (KUMJ). 2005;3:239-42.

50. Bosan A, Qureshi H, Bile KM, Ahmad I, Hafiz R. A review of hepatitis viral infections in Pakistan. J Pak Med Assoc. 2010; 60:1045-58.

51. Ali M, Idrees M, Ali L, Hussain A, Ur Rehman I, Saleem S, et al. Hepatitis B virus in Pakistan: a systematic review of prevalence, risk factors, awareness status and genotypes. Virol J. 2011;8:102.

52. Qureshi H, Bile KM, Jooma R, Alam SE, Afridi HU. Prevalence of hepatitis B and C viral infections in Pakistan: findings of a national survey appealing for effective prevention and control measures. East Mediterr Health J. 2010;16:S15-23.

53. Aziz S, Khanani R, Noorulain W, Rajper J. Frequency of hepatitis $\mathrm{B}$ and $\mathrm{C}$ in rural and periurban Sindh. J Pak Med Assoc. 2010;60:853-7.

54. Abbas Z, Jeswani NL, Kakepoto GN, Islam M, Mehdi K, Jafri W. Prevalence and mode of spread of hepatitis B and C in rural Sindh, Pakistan. Trop Gastroenterol. 2008;29:210-6.

55. Sheikh NS, Sheikh AS, Sheikh AA, Yahya S, Rafi-U-Shan, Lateef M. Sero-prevalence of hepatitis B virus infection in Balochistan Province of Pakistan. Saudi J Gastroenterol. 2011;17:180-4.

56. Quddus A, Luby SP, Jamal Z, Jafar T. Prevalence of hepatitis B among Afghan refugees living in Balochistan, Pakistan. Int J Infect Dis. 2006;10:242-7.

57. Khanani MR, Ansari AS, Khan S, Somani M, Kazmi SU, Ali SH. Concentrated epidemics of HIV, HCV, and HBV among Afghan refugees. J Infect. 2010;61:434-7.

58. Ali SA, Donahue RMJ, Qureshi H, Vermund SH. Hepatitis B and hepatitis $\mathrm{C}$ in Pakistan: prevalence and risk factors. Int $J$ Infect Dis. 2009;13:9-19.

59. Kazmi K, Ghafoor A, Qureshi WA. Mother-infant transmission of hepatitis B in Pakistan. Pakistan J Med Res. 2003;42:152-6.

60. Mumtaz K, Hamid S, Ahmed S, Moatter T, Mushtaq S, Khan A, et al. A study of genotypes, mutants and nucleotide sequence of hepatitis B virus in Pakistan: HBV genotypes in pakistan. Hepat Mon. 2011;11:14-8.

61. Jazayeri SM. Commentary on: A study of genotype, mutants, and nucleotide sequence of HBV in Pakistan: genotypes, mutants, and nucleotide sequence of HBV. Hepat Mon. 2011;11:289-91.

62. Awan Z, Idrees M, Amin I, Butt S, Afzal S, Akbar H, et al. Pattern and molecular epidemiology of Hepatitis B virus genotypes circulating in Pakistan. Infect Genet Evol. 2010;10:1242-6.

63. Khan S, Attaullah S. Share of Afghanistan populace in hepatitis B and hepatitis C infection's pool: is it worthwhile? Virol J. 2011;8:216.

64. Nasir A, Todd CS, Stanekzai MR, Bautista CT, Botros BA, Scott PT, et al. Prevalence of HIV, hepatitis B and hepatitis C and associated risk behaviours amongst injecting drug users in three Afghan cities. Int J Drug Policy. 2011;22:145-52.

65. Todd CS, Abed AMS, Strathdee SA, Scott PT, Botros BA, Safi $\mathrm{N}$, et al. HIV, hepatitis C, and hepatitis B infections and associated risk behavior in injection drug users, Kabul, Afghanistan. Emerg Infect Dis. 2007;13:1327-31.

66. Attaullah S, Rehman S, Khan S, Ali I, Ali S, Khan SN. Prevalence of Hepatitis B virus genotypes in HBsAg positive individuals of Afghanistan. Virol J. 2011;8:281.

67. Merican I, Guan R, Amarapuka D, Alexander MJ, Chutaputti A, Chien RN, et al. Chronic hepatitis B virus infection in Asian countries. J Gastroenterol Hepatol. 2000;15:1356-61.

68. Gupta S, Gupta R, Joshi YK, Singh S. Role of horizontal transmission in hepatitis B virus spread among household contacts in North India. Intervirology. 2008;51:7-13

69. Kidd-Ljunggren K, Holmberg A, Blackberg J, Lindqvist B. High levels of hepatitis B virus DNA in body fluids from chronic carriers. J Hosp Infect. 2006;64:352-7

70. Komatsu H, Sugawara H, Inui A, Nagamine K, Hiejima E, Sogo $\mathrm{T}$, et al. Does the spread of hepatitis B virus genotype A increase the risk of intrafamilial transmission in Japan? J Infect Chemother. 2011;17:272-7.

71. Wai CT, Fontana RJ. Clinical significance of hepatitis B virus genotypes, variants and mutants. Clin Liver Dis. 2004;8:321-52.

72. Cheng H, Su H, Wang S, Shao Z, Men K, Li M, et al. Association between genomic heterogeneity of hepatitis B virus and intrauterine infection. Virology. 2009;387:168-75

73. Chan CY, Lee SD, Lo KJ. Legend of hepatitis B vaccination: the Taiwan experience. J Gastroenterol Hepatol. 2004;19:121-6. 